\title{
Customer Portfolio Management: Toward a Dynamic Theory of Exchange Relationships
}

Management of an entire portfolio of customers who are at different relationship stages requires a dynamic theory of exchange relationships that captures the trade-offs between scale economies and lifetime customer value. This article contributes to the understanding of relationship management by developing a typology of exchange relationship mechanisms and a model of relationship dynamics and by simulating the model to provide guidelines for customer portfolio management. An important insight from the research is that a key to the creation of value through closer relationships lies in bringing weaker relationships into a portfolio in the first place. Another insight is that firms that position themselves toward offerings with low economies of scale, such as personal services, must build closer relationships to create value.

$\mathbf{T}$ he past half century has brought dramatic shifts in the underlying goals of marketing and strategic market planning. In the decades of growth following World War II, economies of scale and scope were central, because profits were primarily a reflection of market share (Buzzell and Gale 1987). As markets throughout North America, Europe, and parts of Asia matured in the 1980s and into the 1990 s, the lifetime value of customers became a central marketing goal (Fornell 1992). The increasingly global economy is now marked by large technology shocks, from such sources as the Internet and e-commerce, to the fields of biotechnology, information technology, and energy technology. The result is a mix of mature and growth markets and their associated risks and returns, where the goal of a given firm's marketing strategy is not so clear. These changes underscore the need for a theory of exchange relationships that encompasses the basic trade-offs between increasing market share to achieve economies of scale and the lifetime value of customers.

"Offensive marketing" typically refers to activities aimed at increasing the size of a firm's customer base, and "defensive marketing" refers to activities aimed at existing customers, such as customer retention (Fornell and Wernerfelt 1987) and service recovery efforts (Smith, Bolton, and Wagner 1999). Current thought in marketing theory and practice is that defensive marketing has become more profitable, and the implication is that companies should allocate resources to build more cooperative and long-lasting rela-

\footnotetext{
Michael D. Johnson is D. Maynard Phelps Professor of Business Administration and Professor of Marketing, University of Michigan Business School, University of Michigan (e-mail: mdjohn@umich.edu). Fred Selnes is Professor of Marketing, Norwegian School of Management BI (e-mail: f.selnes@bi.no). The authors thank Dave Stewart and the three anonymous JM reviewers for their constructive comments on previous drafts of the article. The authors' names are in alphabetical order, and they have contributed equally to the article.
}

tionships with their customers (Day 2000; Rust, Zeithaml, and Lemon 2000; Storbacka, Strandvik, and Grönroos 1994). We couch this argument in the larger question of how a firm should invest in an entire portfolio of relationships at different levels of cooperation to create value (Christopher, Payne, and Ballantyne 2002; Gummesson 2000; Hunt 2002). The relationship marketing literature recognizes the need to build portfolios of relationships or relational resources (Hunt 1977) to increase a firm's return on relationships (Gummesson 1994). However, as Hunt (2002) points out, there is significant ambiguity surrounding relationship portfolio decisions, because the portfolios are not selected at a particular point in time; rather, they take time to develop. Therefore, investments in a customer portfolio should be a function of underlying firm, customer, and industry characteristics.

In particular, customer relationship theories must grow to include the accumulated effect that the number of customers (i.e., relationships) has on economies of scale and the resultant cost structure of competing firms. This underscores the need to differentiate relationships on the basis of how value is created and to link value creation within individual relationships to overall value creation for a firm. An important consequence is that offensive and defensive marketing strategies become more comprehensive concepts than has been previously considered. As we argue subsequently, offensive marketing not only increases a customer base but also provides a basis for relationship development, whereas defensive marketing works not only to retain current customers but to create additional value with those customers through relationship development.

The purpose of this article is to move relationshipmanagement research toward a dynamic theory of how to build value for a firm across an entire portfolio of customer relationships. We first develop a typology of exchange relationship mechanisms that captures fundamentally different forms of value creation. The different forms are a function of customers' capabilities and problem-solving behavior as 
well as suppliers' capabilities and resource-allocation decisions. Because the different types of relationships imply different profit mechanisms, sellers' marketing strategies should encompass an entire portfolio of customers at different relationship levels. We refer to this process as "customer portfolio management." We then introduce a model of customer portfolio lifetime value (CPLV) that links value creation within individual customer relationships with overall value creation for a firm. The model provides a basis for understanding when and when not to grow relationships. Finally, we use the framework, model, and simulation to develop a series of postulates and propositions regarding the dynamics of customer portfolios and portfolio management. We begin by developing a theoretical framework that connects customer-supplier relationships to industry factors and societal institutions. The framework takes a dynamic approach that extends existing theories of competition in marketing (Alderson 1965; Dickson 1992; Hunt and Morgan 1995, 1996) and provides the basis for our relationship typology and CPLV model.

\section{Toward a Theory of Exchange Relationships}

In general, marketing scholars agree that the fundamental phenomenon to be explained, predicted, and controlled in the dynamics of the marketplace is the exchange relationship (Bagozzi 1975; Hunt 1976, 1983; Kotler 1972). The purpose of an exchange relationship is to connect a customer's needs with a supplier's resources and offerings. We use the terms "customer" and "supplier" herein to apply to both business-to-consumer and business-to-business relationships. From a supplier's perspective, value creation is a process of understanding the heterogeneity of customer needs, developing products (goods and services) to fill those needs, and matching customers to products through marketing activities in competition with other suppliers (Alderson 1957, 1965; Reekie and Savitt 1982). From the customer's perspective, the customer chooses the supplier or suppliers that provide the highest expected benefits less any associated costs and risk, where benefits encompass a bundle of qualities, processes, and/or capabilities (Murphy and Enis 1986).

At a basic level, an exchange relationship serves its purpose when the customer has received the product and paid for it. However, in some relationships, the customer and the supplier collaborate, share information, socialize, integrate or link activities, and even commit future resources to the relationship. Relationships are formed to create economic value more effectively than what may be achieved through the market (price) mechanism. This phenomenon is by no means new, either in the marketplace or in economic theory. In 1937, Coase had already referred to forming relationships in those cases in which short-term contracts would be unsatisfactory (e.g., with services and labor). Richardson (1972) argued that relationships in the form of ex ante cooperation are more likely, even necessary, when the activities of the buyer and the seller are complementary but dissimilar.

Following these arguments, we define an exchange relationship as a mechanism for creating value through the coordination of production, consumption, and related economic activities between a customer and a supplier. There are various exogenous factors that influence how value is created in exchange relationships. In this article, we explore in detail how firm, customer, and industry factors are likely to affect economic activity organized in relationships. Our exchange relationship framework is presented in Figure 1. The central concept in the framework is the nature of the exchange relationship mechanism. The value created in an exchange relationship is a direct function of both the customer's and the supplier's capabilities and strategies.

The strategy of the customer in the market-matching process is to know when and where to solve problems (Howard 1977, 1983; Murphy and Enis 1986) to identify the supplier that is perceived as the best in terms of overall benefits less the costs and risks involved. This problem solving has historically been linked to discrete product decisions (transactions). We propose that customer problem solving be conceptualized more broadly to include implicit or explicit relationship decisions; that is, a customer evaluates both the expected benefits versus the costs of a given relationship (versus the same relationship with other suppliers) and the benefits versus the costs of alternative forms of that relationship. A customer's capability to evaluate these tradeoffs affects his or her ability either to convert to a closer relationship or to change suppliers. Customers' motivation to solve problems is a direct function of the homogeneity versus the heterogeneity of demand (Alderson 1965). The more heterogeneous the demand, the greater is the benefit of finding an alternative that better fits customer needs relative to the costs and risks incurred.

The strategy of the supplier in this exchange relationship is to provide an offering and to organize resources to match the needs of the market to create the best return on investment and a sustainable competitive advantage (Day 1997; Dyer and Singh 1998). We propose and subsequently describe three different strategies for how customer value is created to accomplish these goals: parity value, differential value, and customized value.

A firm's efforts to evaluate the relative value of different exchange relationships occur within a dynamic competitive environment in a state of constant change (Day and Wensley

\section{FIGURE 1} Exchange Relationship Framework

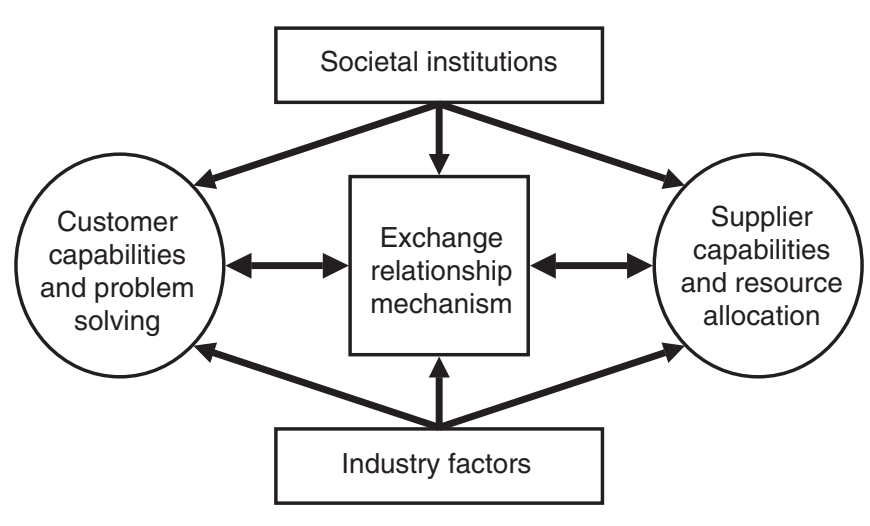


1988; Dickson 1992; Hayek 1978; Hunt and Morgan 1995). Industry factors naturally directly affect customer capabilities and problem solving, supplier capabilities and resource allocation, and the exchange relationship mechanism. The direct effects of industry factors in Figure 1 capture the influence of an industry's norms and opportunities as exogenous variables, or "rules of competition," that come with competing in a particular industry (Porter 1985), as when economies of scale are high or low. Similarly, societal institutions capture the customs, laws, and institutions of society in general (North 1990) that influence exchange relationships. For example, public service agencies and utilities are often required by law to serve segments of customers that are not profitable. The indirect effects of industry factors and societal institutions on exchange relationships capture the factors that influence customers' or suppliers' benefits, costs, and risks of entering or maintaining a relationship.

The development of an exchange relationship also depends directly on the ability and motivation of both the customer and the supplier to participate. For example, when a supplier wants to move a relationship to a higher degree of commitment, the move is contingent on the customer's willingness and ability to contribute. Therefore, in an understanding of exchange relationships, both sides must be understood simultaneously. At the same time, the exchange relationships that exist or evolve in the marketplace have some effect on what customers and suppliers do. Thus, we posit a reciprocal relationship between both customer and supplier decisions and the exchange relationship mechanism in Figure 1.

Several researchers in marketing have addressed differences among exchange relationship mechanisms and have proposed typologies based on, for example, the differences between products and services (Berry 1980; Shostack 1977), the degree and form of collaboration (Day 2000; Heide 1994), industrial versus consumer markets (Webster 1978), and the potential value of a firm's customer portfolio (Dickson 1983; Fiocca 1982; Krapfel, Salmond, and Spekman 1989). In the context of our framework and discussion, it is more parsimonious to focus on differences in how value is created (i.e., the mechanism for coordination of production, consumption, and related economic activities between a customer and a supplier). We subsequently present three types of relationships: acquaintances, friends, and partners. The labels in this typology are similar to those in the work of Krapfel, Salmond, and Spekman (1989), but the definitions are different.

Our goal is to link value creation at the level of the individual relationships with value creation for the firm as a whole. The individual relationships are building blocks for understanding the value created across an entire customer portfolio. Although individual exchange relationships are primarily economic relationships in our typology, they retain social meaning. As relationships evolve from acquaintances, to friends, to partners, the trust and commitment in these relationships suggests that the social mechanism for creating economic value changes. However, unlike purely social relationships, customers and suppliers are likely to dissolve any form of exchange relationship if the economics of the relationship thus dictate.

\section{From Strangers to Acquaintances}

Strangers are customers and suppliers in a preawareness and/or pretransaction period. At the industry level, strangers may be conceptualized as customers that have not yet entered the market. At the firm level, they may include customers of competing suppliers. As soon as there has been a transaction in which awareness and trial are achieved (Ehrenberg 1972), a minimum of familiarity is established, the supplier and customer become acquaintances, and an exchange relationship is established. In this case, suppliers need only provide a value proposition to customers that is on par with competitors, or parity value. Through replication of processes and accumulated volume, suppliers gain experience, learn to improve production efficiencies, and gain a cost advantage relative to those with less experience and volume (Ettlie 2000; Porter 1985).

For a customer, an acquaintanceship is effective as long as the supplier provides the product in a satisfactory way at a price that is perceived as fair. With repetitive interaction, the customer gains experience and becomes familiar with the supplier's products and services. This reduces uncertainty about expected benefits and costs of continuing the relationship and thus enhances the relative attractiveness of the supplier relative to other suppliers (Hoch and Deighton 1989). Repetitive interaction creates familiarity with the customer, which facilitates marketing, sales, and service. Thus, an acquaintance relationship facilitates transactions primarily through the reduction of a customer's perceived risk and a supplier's costs.

Given the nature of acquaintanceships and their focus on parity value, standardization, and repetition, the potential for a firm to develop a sustainable competitive advantage through relationship activities is limited. However, competitors can create value through acquaintances, which is difficult to imitate, by learning from the transactions as a whole. For example, Amazon.com has created value even with acquaintances through a highly developed order and sales system. By processing and organizing historical idiosyncratic transaction data from a customer and comparing it with data from other customers, the system is able to generate cross-selling opportunities.

\section{From Acquaintances to Friends}

A major tenant of dynamic theories of competition is that competitors are constantly trying to adapt to changing customer needs (Alderson 1965; Dickson 1992; Hunt and Morgan 1995, 1996). As a result, suppliers diversify their product portfolios to target both old and new customer segments with differentiated offerings (Buzzell 1966) and superior value propositions (Best 2000). The key to the creation of value and profit is no longer just parity, standardization, and repetitive operations, it is also convincing customers to pay a premium for superior performance.

A firm's potential to develop sustainable competitive advantage through friendships should be higher than for acquaintances. Because the offering is more unique and the customer comes to trust that uniqueness, a competitive advantage is created. The activities that link customer and supplier are also more unique and more difficult to imitate, especially as they grow into a series of linked activities 
(Gustafsson and Johnson 2003). For example, IKEA is an international furniture retailer that creates value for both customers and suppliers through a series of linked activities that include low-cost manufacturing; in-house design; and direct involvement of customers in the service, selection, and assembly activities.

As suppliers move from supplying parity value to differential value, the exchange relationship transforms from acquaintance to friendship. Psychologically, the transition from acquaintanceship to friendship requires the development of trust in the relationship (Morgan and Hunt 1994), be it to a brand, an individual (e.g., a service provider), or an entire organization (e.g., industrial buying). Customers not only become familiar with a particular supplier or suppliers but also come to trust that the supplier provides superior value. Suppliers provide a diversified product or products that meet the needs of a particular market segment better than competitors. A natural consequence is that customers require more information, as through advertising and word of mouth. The customer also provides more information to the supplier (e.g., in the form of market research) to enable suppliers to identify changes in customers needs, communicate them through the organization, and use the information to improve products and services (Kohli and Jaworski 1990; Narver and Slater 1990).

\section{From Friends to Partners}

Not captured thus far in our typology is a partnership that reaches the level of ex ante cooperation and coordination of production and supply. Research on industrial buyer behavior provides the psychological foundation for understanding the transition from friends to partners. In their commitmenttrust theory of relationships, Morgan and Hunt (1994) argue that the longevity, level of cooperation, and acquiescence in an exchange relationship are predicated on not just trust but also relationship commitment. Drawing on research both inside and outside of marketing (Cook and Emerson 1978; Moorman, Zaltman, and Deshpandé 1992), Morgan and Hunt define commitment as "an exchange partner believing that an ongoing relationship with another is so important as to warrant maximum efforts at maintaining it" (p. 23).

The collaborative coordination of complementary activities (Coase 1937; Richardson 1972) requires suppliers to provide more customized value, which has several implications for how the relationship should be managed (Cannon and Perrault 1999; Heide 1994). Suppliers must use customer knowledge and information systems to deliver highly personalized and customized offerings to create the highest level of congruence between the heterogeneity of demand and supply (Edvardsson et al. 2000). The key to profitability becomes a supplier's ability to organize and use information about individual customers more effectively than competitors. Customers benefit from suppliers whose customer knowledge and information systems enable them to deliver highly personalized and customized offerings (Huffman and Kahn 1998; Pine and Gilmore 1998; Pine, Peppers, and Rodgers 1995). However, customers must be willing to pay a price premium or to commit themselves to the supplier for an extended period of time (Van de Ven 1976; Williamson
1983). Over time, the relationship may evolve through continuous adaptation and commitment (Dwyer, Schurr, and Oh 1987; Johanson, Hallén, and Seyed-Mohamed 1991), and the parties may become increasingly interdependent. The relationship may advance from having only a matching purpose to becoming a source of sustainable competitive advantage (Dyer and Singh 1998; Hunt 1997, 2002; Selnes and Sallis 2003).

That trust is a necessary but not sufficient condition for partnerships is consistent with Spekman's (1988) argument that trust provides a platform or "cornerstone" from which more long-term commitments are built. Similarly, Morgan and Hunt (1994) theorize that the creation of trust leads to the creation of commitment. This follows from social exchange theory and its concept of generalized reciprocity (McDonald 1981), which holds that trust breeds trust, which ultimately increases commitment and results in a shift from short-term exchanges to long-term relationships. In support of the theory, Morgan and Hunt (1994) and Moorman, Zaltman, and Deshpandé (1992) find that trust has a significant effect on relationship commitment and resultant loyalty among industrial customers. Commitment is also a necessary condition for customers to extend the time perspective of a relationship (Spekman 1988). Just as a customer's trust in brand concepts enables friends to purchase products routinely yet in an arm's-length way, the deepening of trust and the establishment of commitment further reduce the customer's need to solve problems in the traditional sense of "finding a better alternative." This trust and commitment are not limited to business-to-business contexts. Johnson and colleagues (2001) find that relationship commitment plays a direct role in building end-user loyalty as well.

Table 1 summarizes our exchange relationship typology and the basic arguments about how value is created in the different types. From a customer's problem-solving perspective, the formation of satisfaction, trust, and commitment corresponds to the customer's willingness to engage in an exchange relationship as an acquaintance, friend, and partner, respectively. From a supplier's resource-allocation perspective, the delivery of parity value, differential value, and customized value corresponds to the supplier's ability and motivation to create an acquaintance, friend, or partner. The implication is that as customers make the transition from satisfaction-based acquaintanceships to trust-based friendships to commitment-based partnerships, we expect that both the value and the length of cooperation increase.

\section{Relationship Development and Switching Behavior}

Our framework and typology suggest that customer relationships progress over time to closer and closer forms of value creation, though there are individual cases in which the progression of relationships is different. A relationship between a supplier and a customer may be established directly at a friendship level without progressing through the acquaintance stage. Customers may move from being acquaintances with one supplier to friends with another supplier because the competitor's offering has a superior value proposition. Here, the trust required of friendships may be 
TABLE 1

A Typology of Exchange Relationships

\begin{tabular}{|c|c|c|c|}
\hline & Acquaintances & Friends & Partners \\
\hline Product offering & $\begin{array}{l}\text { Parity product as a form of } \\
\text { industry standard }\end{array}$ & $\begin{array}{l}\text { Differentiated product } \\
\text { adapted to specific market } \\
\text { segments }\end{array}$ & $\begin{array}{l}\text { Customized product and } \\
\text { dedicated resources } \\
\text { adapted to an individual } \\
\text { customer or organization }\end{array}$ \\
\hline $\begin{array}{l}\text { Source of competitive } \\
\text { advantage }\end{array}$ & Satisfaction & Satisfaction + trust & $\begin{array}{l}\text { Satisfaction }+ \text { trust }+ \\
\text { commitment }\end{array}$ \\
\hline Buying activity & $\begin{array}{l}\text { Satisfaction facilitates and } \\
\text { reinforces buying activity } \\
\text { and reduces need to } \\
\text { search for market } \\
\text { information. }\end{array}$ & $\begin{array}{l}\text { Trust in supplier is needed } \\
\text { to continue the buying } \\
\text { activity without perfect } \\
\text { information. }\end{array}$ & $\begin{array}{l}\text { Commitment in the form of } \\
\text { information sharing and } \\
\text { idiosyncratic investments is } \\
\text { needed to achieve } \\
\text { customized product and to } \\
\text { adjust product continuously } \\
\text { to changing needs and } \\
\text { situations. }\end{array}$ \\
\hline $\begin{array}{l}\text { Selling and servicing } \\
\text { activities }\end{array}$ & $\begin{array}{l}\text { Familiarity and general } \\
\text { knowledge of customer } \\
\text { (identification) facilitates } \\
\text { selling and serving. }\end{array}$ & $\begin{array}{l}\text { Specific knowledge of } \\
\text { customer's connection to } \\
\text { segment need and situation } \\
\text { facilitates selling and } \\
\text { serving. }\end{array}$ & $\begin{array}{l}\text { Specific knowledge of } \\
\text { customer's need and } \\
\text { situation and idiosyncratic } \\
\text { investments facilitates } \\
\text { selling and serving. }\end{array}$ \\
\hline Acquisition costs & $\begin{array}{l}\text { Low: Generally low but } \\
\text { depends on industry factors } \\
\text { such as market growth, } \\
\text { satisfaction with competing } \\
\text { alternatives, distribution, } \\
\text { and media availability. }\end{array}$ & $\begin{array}{l}\text { Medium: Acquisition and/or } \\
\text { conversion costs increase } \\
\text { with degree of } \\
\text { differentiation in product } \\
\text { (perceived risk), established } \\
\text { preferences for competing } \\
\text { alternatives, and availability } \\
\text { of segment specific } \\
\text { channels and media. }\end{array}$ & $\begin{array}{l}\text { High: Acquisition and/or } \\
\text { conversion costs increase } \\
\text { with degree of } \\
\text { customization and level of } \\
\text { idiosyncratic investments } \\
\text { from one or both sides. }\end{array}$ \\
\hline Time horizon & $\begin{array}{l}\text { Short: Generally short } \\
\text { because the buyer can shift } \\
\text { supplier without much effort } \\
\text { or cost. }\end{array}$ & $\begin{array}{l}\text { Medium: Generally longer } \\
\text { than acquaintance } \\
\text { relationships because trust } \\
\text { in a differentiated position } \\
\text { takes a longer time to build } \\
\text { and imitate. }\end{array}$ & $\begin{array}{l}\text { Long: Generally long } \\
\text { because it takes time to } \\
\text { build and replace } \\
\text { interconnected activities } \\
\text { and to develop a detailed } \\
\text { knowledge of a customer's } \\
\text { need and the unique } \\
\text { resources of a supplier to } \\
\text { commit resources to the } \\
\text { relationship. }\end{array}$ \\
\hline $\begin{array}{l}\text { Sustainability of competitive } \\
\text { advantage }\end{array}$ & $\begin{array}{l}\text { Low: Generally low, but } \\
\text { competitors can vary in } \\
\text { how they build unique value } \\
\text { into selling and serving } \\
\text { even if the product is a } \\
\text { form of industry standard. }\end{array}$ & $\begin{array}{l}\text { Medium: Generally medium } \\
\text { but depends on } \\
\text { competitors' ability to } \\
\text { understand heterogeneity } \\
\text { of customer needs and } \\
\text { situations and the ability to } \\
\text { transform this knowledge } \\
\text { into meaningful, } \\
\text { differentiated products. }\end{array}$ & $\begin{array}{l}\text { High: Generally high but } \\
\text { depends on how unique } \\
\text { and effective } \\
\text { interconnected activities } \\
\text { between customer and } \\
\text { supplier are organized. }\end{array}$ \\
\hline
\end{tabular}

acquired not through direct experience but through brand building, personal selling, and so forth. Customers may also move directly to the partnership level, such as when an industrial customer decides to outsource its information technology or customer service activities completely to a partner with which it has no previous experience.
However, at an aggregate level, we assume that a supplier's customers move progressively from strangers, to acquaintances, to friends, to partners. This is consistent with the evolution of market growth as it relates to the diffusion of innovation within a product life cycle (Mahajan, Muller, and Bass 1995). A natural consequence of market growth is 
that customer demand becomes more heterogeneous as a wider variety of customers (and customer needs) emerges (Dickson 1992). In response to this heterogeneity, firms constantly innovate, putting forward alternative systems, service processes, and products to create value for and to attract customers (Day and Wensley 1988). Thus, as markets grow, we expect to observe the emergence of differentiated and customized products with a mix of relationships that include an increasing number of friends and partners over time.

The likelihood of observing this progression of relationship levels should vary by firm, customer, and industry. The greater the lifetime values of customers, the more incentive the suppliers have to pursue closer relationships. The more that sellers segment the market to meet particular customer needs, the more incentive customers have to pursue closer relationships. The more intense the competition in any particular segment, the more customers are likely to switch because of the abundance of substitutes. For example, consider cases in which both the costs of market entry and the value of building close relationships are high. This might describe technologically intensive industries in which customers and suppliers benefit significantly from close cooperation. Although the probability of any given firm being able to create acquaintances is low, as a result of entry barriers, the probability of moving the acquaintances to become partners may be higher. In contrast, consider cases in which both the costs of entry and the benefits of partnership are both low, such as in Internet retailing. In this case, it may be easier to create acquaintances than to move customers to a friendship or partnership stage.

On the basis of our typology, we believe that this relationship progression should systematically affect both the propensity for customers to switch and the costs incurred either to gain customers from competitors or to move them to an even closer relationship. The strength of a closer relationship creates a stickiness that lowers the probability of customer switching (Bendapudi and Berry 1997; Johnson et al. 2001). Customers simply have a diminishing need to solve problems or to shop around. Closer relationships also increase the costs that a competitor incurs to induce switching at a given relationship level (Fornell 1992; Fornell and Wernerfelt 1987). The costs of converting a customer from level to level should similarly increase as customers move from being strangers to being acquaintances, friends, and partners. The cost increases are directly related to the creation of parity value, differential value, and customized value (as is shown in Table 1) and, at a general level, the relationship-specific investments incurred when a firm seeks closer customer relationships (Bendapudi and Berry 1997; Williamson 1981). Thus, the costs of converting customers to a higher-level relationship or gaining customers from competitors at a given level should increase, and the probability of switching should decrease as customers progress from strangers to acquaintances, to friends, to partners. Closer relationships also create premium value for firms, which is a basic tenant of the customer lifetime value (CLV) argument (Fornell et al. 1996; Gummesson 2002; Rust, Zeithaml, and Lemon 2000). It has been argued that customers that are closer to the firm tend to buy more (because they are better acquainted with the firm's offerings), cost less to serve (because the firm knows them better), and are less price sensitive (because they have higher switching costs; Libai, Narayandas, and Humby 2002).

We state our arguments about the dynamics of the relationship typology as a series of postulates. Our arguments about switching probabilities and relationship costs and premiums are stated formally as follows:

Postulate 1: As customers progress toward a closer relationship with suppliers, (a) the probability of customers switching to competitors decreases, (b) the costs of gaining customers from competitors at a given relationship level increase, (c) the costs of converting customers to an even closer relationship increase, and (d) revenue premiums increase.

Firms differ in their resources and resulting marketing capability to learn and to create a competitive advantage with respect to the costs and probabilities of attracting customers and developing relationships (Baker and Sinkula 1999; Day 1984, 2000; Hunt and Morgan 1995, 1996). Some suppliers are simply better at adapting to the heterogeneity of customer demand over time by learning from customers and competitors and by implementing what they learn (Dickson 1992). The relational view of developing competitive advantage identifies relationship learning (e.g., interfirm knowledge sharing) as an important avenue for the creation of differential relationships and "supernormal" profits in relationships (Dyer and Singh 1998; Pine, Peppers, and Rogers 1995; Selnes and Sallis 2003). A firm's capability to learn from and about its market and customers has several direct implications for relationship development and how value is created in its customer relationships, which we state formally as follows:

Postulate 2: The stronger the dynamic marketing capabilities of a firm, (a) the lower is the probability that a customer will switch to competitors, (b) the higher is the probability that a customer will switch from competitors, (c) the higher is the probability of converting customers to closer relationships, (d) the lower is the cost of converting customers to closer relationships, and (e) the higher is the revenue premium from closer relationships.

Aside from market growth and the heterogeneity of demand and supply that follow, one of the most important industry factors that affects value creation is economies of scale (Porter 1985, 1995). Economies of scale relate to the generation of market-level efficiencies through increased volume (Best 2000; Milgrom and Roberts 1992). The process and production efficiencies gained through accumulated production and resultant knowledge lead to a drop in cost per transaction or unit sold, which decreases at the margin over time. From a customer portfolio standpoint, this creates a fundamental resource-allocation trade-off for managers. Should resources be allocated to create simple transactions and growth as a means of leveraging systemwide economies of scale, or should resources be allocated to build relationships through cooperation to increase the lifetime value of customers?

These economies of scale should directly affect the attractiveness of different types of customers in a customer portfolio. In industries in which economies of scale are large 
(e.g., a manufacturer of commodity goods), there should be greater value created by just having customers in the portfolio, even if they are on-again/off-again acquaintances. In industries in which economies of scale are much smaller, the creation of closer relationships that leverage the lifetime value of customers should be more important. For example, the larger the service component of a product offering, the lower are the economies of scale. Because services are more customized to individual needs and involve the human resources of the firm, it is more difficult to increase quality without lowering productivity (Anderson, Fornell, and Rust 1997; Huff, Fornell, and Anderson 1996). However, even service industries vary in their degree of scale effects, such as when self-service technologies bring some efficiency to particular service activities (Edvardsson et al. 2000). Another straightforward implication of increased economies of scale is that the overall value of a customer portfolio (i.e., CPLV) should increase as a result of cost reduction. We state the dynamics regarding economies of scale as follows:

Postulate 3: As the scale advantages of growth in a market increase, (a) overall CPLV increases, and (b) the contribution of distant relationships increases relative to closer relationships.

\section{CPLV}

How should firms allocate resources to attract customers and move relationships to higher forms of value creation to maximize profits and develop a sustainable competitive advantage? The answer to this question requires an understanding of the dynamics of value creation and the profitability of the different types of relationships over time. In every market period, firms must decide whether to incur the costs required to create acquaintances through parity value, friends through differential value, and partners through customized value. We do not consider discounted cash flows here for several reasons. The first is to keep the defined time period open to accommodate both relatively short and relatively long product life cycles (e.g., high-technology versus low-technology products; Ettlie 2000). The second reason is to keep the model and discussion as parsimonious as possible. Finally, the impact on our model is straightforward. As relationships take time to develop, a discount factor simply decreases the value of closer relationships with respect to distant relationships.

In the following sections, we develop a model of CPLV and a set of propositions that capture how the market dynamics and firm capabilities in Postulates 1-3 affect the evolution and value of a supplier's customer portfolio of relationships over time. We use a series of logical experiments, or simulations, to operationalize the CPLV model under various conditions. We produced values of the different parameters used in the simulation; we did not take them from any particular market or markets. In accordance with Moorthy (1993), the focus in theoretical modeling is on internal validity. The purpose is to construct an environment, or model, in which actions take place. In this sense, our simulations do not test the theory per se. Rather, they operationalize the theoretical model, or "produce the effects by logical argument," and thus help the researcher "construct cause-effect explanations of marketing phenomena" (Moorthy 1993, p. 94). Although the testing of our postulates or assumptions and resulting propositions is beyond the scope of this research, they are ultimately tested by their predictions in different areas of applicability.

\section{The CPLV Model}

Marketing scholars have devoted considerable attention in recent years to operationalizing and estimating CLV models, which examine expected profits over time for individual customers (Blattberg, Getz, and Thomas 2001; Gupta and Lehmann 2003), new versus existing customers (Hogan, Lemon, and Rust 2002), and market segments (Libai, Narayandas, and Humby 2002). The overriding emphasis in these models is how to increase the lifetime value of individual customers as assets (Hogan, Lemon, and Rust 2002; Hunt 1997). Although we use this as a foundation, our point of departure is that we focus on value created through an entire portfolio of customers at different relationship stages over time, or CPLV.

The problem for any given supplier $\mathrm{s}$ is to maximize CPLV as the sum of the value of acquaintances (A), friends (F), and partners (P). To specify CPLV more explicitly for a given firm over time, we first specify the total number of acquaintances $\left(\mathrm{A}_{\mathrm{st}}\right)$, friends $\left(\mathrm{F}_{\mathrm{st}}\right)$, and partners $\left(\mathrm{P}_{\mathrm{st}}\right)$ for supplier $\mathrm{s}$ at time $\mathrm{t}$ as follows:

$$
\begin{gathered}
A_{s t}=A_{s t-1}+A_{\text {st Converted }}+A_{\text {st Gained }}-A_{\text {st Lost }} \\
-F_{\text {st Converted }}, \\
\mathrm{F}_{\text {st }}=\mathrm{F}_{\text {st }-1}+\mathrm{F}_{\text {st Converted }}+\mathrm{F}_{\text {st Gained }}-\mathrm{F}_{\text {st Lost }} \\
-\mathrm{P}_{\text {st Converted }} \text { and } \\
\mathrm{P}_{\mathrm{st}}=\mathrm{P}_{\mathrm{st}-1}+\mathrm{P}_{\text {st Converted }}+\mathrm{P}_{\text {st Gained }}-\mathrm{P}_{\text {st Lost }},
\end{gathered}
$$

where the subscripts "Converted," "Gained," and "Lost" denote relationships converted from one level to another, relationships gained from the competition at a given level, and relationships lost to the competition at a given level for supplier s at time $t$, respectively. Thus, $\mathrm{A}_{\mathrm{st}}$ Converted is the number of strangers new to the market that are converted to acquaintances, and $\mathrm{A}_{\mathrm{st} \text { Gained }}$ is the number of competitors' customers gained as acquaintances by supplier $s$ at time $t$. Equations 1-3 take into account a supplier's ability to create closer relationships, the gain and loss of customers at a given level (i.e., switching behavior), and the attrition of customers to higher-level relationships. To estimate the value of overall CPLV for supplier s at time t, we must also define parameters to capture the relative costs and revenues involved, where

$\mathrm{UC}_{\mathrm{st}}=$ unit cost for supplier s at time $\mathrm{t}$;

$\mathrm{CR}_{\mathrm{st}}=$ base customer revenue for supplier s at time $\mathrm{t}$;

$\mathrm{FP}_{\mathrm{st}}=$ friendship premium for supplier $\mathrm{s}$ at time $\mathrm{t}$;

$\mathrm{PP}_{\mathrm{st}}=$ partner premium for supplier $\mathrm{s}$ at time $\mathrm{t}$;

$\mathrm{AC}_{\mathrm{st}}$ Conversion, $\mathrm{FC}_{\mathrm{st}}$ Conversion, and $\mathrm{PC}_{\mathrm{st}}$ Conversion $=$ acquaintance, friend, and partner cost of conversion, respectively, for supplier $\mathrm{s}$ in time $\mathrm{t}$; and

$\mathrm{AC}_{\mathrm{st} \text { Gaining }}, \mathrm{FC}_{\mathrm{st} \text { Gaining }}$, and $\mathrm{PC}_{\mathrm{st} \text { Gaining }}=$ acquaintance, friend, and partner cost of gaining, respectively, for supplier s in time $t$. 
The unit cost figure is a percentage of the economies of scale for the industry, based on a firm's market share. The costs apply to every customer in the portfolio. The base customer revenue similarly reflects the revenues that apply to every customer in the portfolio, and the premiums for converting customers to friendships and partnerships are the marginal profit (additional ongoing revenue - additional ongoing cost) captured as a result of moving customers to closer relationships. Finally, the costs of conversion and gaining represent the costs of moving a customer to a closer relationship and enticing customers to switch from a competitor, respectively.

The overall value of CPLV is the number of customers at each relationship stage multiplied by the total revenues less costs for each customer, less the costs attributed to converting and gaining customers, all aggregated over a defined time period n. Specifically:

$$
\begin{aligned}
\mathrm{CPLV} & =\sum_{\mathrm{t}=1}^{\mathrm{n}}\left[\mathrm{A}_{\mathrm{st}}\left(\mathrm{CR}_{\mathrm{st}}-\mathrm{UC}_{\mathrm{st}}\right)-\left(\mathrm{A}_{\mathrm{st} \text { Converted }}\right.\right. \\
& \left.\left.\times \mathrm{AC}_{\mathrm{st} \text { Conversion }}\right)-\left(\mathrm{A}_{\mathrm{st} \text { Gained }} \times \mathrm{AC}_{\mathrm{st} \mathrm{Gaining}}\right)\right] \\
& +\sum_{\left[\mathrm{F}_{\mathrm{st}}\left(\mathrm{CR}_{\mathrm{st}}-\mathrm{UC}_{\mathrm{st}}+\mathrm{FP}_{\mathrm{st}}\right)-\left(\mathrm{F}_{\mathrm{st} \text { Converted }}\right.\right.} \\
& \left.\left.\times \mathrm{FC}_{\mathrm{st} \text { Conversion }}\right)-\left(\mathrm{F}_{\mathrm{st} \text { Gained }} \times \mathrm{FC}_{\mathrm{st} \text { Gaining }}\right)\right] \\
& +\sum_{\left[\mathrm{P}_{\mathrm{st}}\left(\mathrm{CR}_{\mathrm{st}}-\mathrm{UC}_{\mathrm{st}}+\mathrm{PP}_{\mathrm{st}}\right)-\left(\mathrm{P}_{\mathrm{st} \text { Converted }}\right.\right.} \\
& \left.\left.\times \mathrm{PC}_{\mathrm{st} \text { Conversion }}\right)-\left(\mathrm{P}_{\mathrm{st} \mathrm{Gained}} \times \mathrm{PC}_{\mathrm{st} \mathrm{Gaining}}\right)\right] .
\end{aligned}
$$

Certain implications for portfolio management follow directly from the CPLV model per se. For example, the costs associated with inducing a customer either to switch from a competitor or to move to a higher-level relationship should have little impact on the relative contribution of acquaintances, friends, and partners over time. Although changes in the costs affect short-term contributions during periods of significant relationship growth, the costs occur only when a given customer converts to a closer relationship or switches from a competitor. In contrast, base customer revenues and relationship premiums are captured for every period that customers are retained. Thus, the cost of either converting customers to higher-level relationships or gaining customers from competitors at a given level have little long-term effect on CPLV, unless the costs are categorically higher than the revenues and premiums. This is consistent with the argument that the costs incurred to gain customers pale in comparison to the revenues that customers generate over time (Fornell et al. 1996; Reichheld 1996).

\section{Operationalizing a Baseline Scenario}

How do the dynamics of the CPLV model actually play out? To gain insight into the model's implications, we conducted a series of simulations to operationalize the model. For brevity, we report only a few of the simulations here so as to highlight the more interesting insights. We develop a baseline scenario (Scenario 1) against which we simulate variations in firm, customer, and industry characteristics through assigning a set of parameters different values. This yields a series of propositions as to how particular firm, customer, and industry characteristics affect CPLV. Our simulations operationalize CPLV for supplier s using Equation 4. On the basis of our postulates and the CPLV model, we operationalize the following parameters: (1) market growth over time, (2) changes in unit costs over time, (3) the cost of converting customers from one relationship level to another, (4) the cost of gaining customers from competitors at a given relationship level, (5) the relationship premium or value created at different relationship levels, (6) the probability of converting customers from one relationship level to another, and (7) the relative probability of gaining versus losing customers from competitors at a given relationship level. The relationship conversion and switching probabilities enable us to determine the total number of acquaintances $\left(\mathrm{A}_{\mathrm{st}}\right)$, friends $\left(\mathrm{F}_{\mathrm{st}}\right)$, and partners $\left(\mathrm{P}_{\mathrm{st}}\right)$ for supplier $\mathrm{s}$ at time $\mathrm{t}$ (i.e., Equations 1-3) as input to Equation 4.

We examined differences in market growth over time within a product life cycle that moves toward one million units sold over 100 market periods. We assume that there is a straightforward diffusion curve for each scenario in our simulation. The quantity sold in period t or $Q_{t}$ is

$$
\mathrm{Q}_{\mathrm{t}}=\mathrm{Q}_{\max } /\left(1+\mathrm{e}^{-(\mathrm{a}+\mathrm{bt})}\right),
$$

where $\mathrm{Q}_{\max }$ is one million units and $\mathrm{a}$ and $\mathrm{b}$ are constants, which we set at -5 and .15 . This yields sales levels over time that follow a logarithmic S-shaped diffusion process (Mahajan, Muller, and Bass 1995) in which there is no extended "time to take off" and some period of market maturity. This enables us to observe differences as the market evolves from introduction, to growth, to maturity. We keep this market growth constant across all scenarios.

Economies of scale represent industry learning related to the reduction in unit costs with market growth. Unit cost at time $\mathrm{T}\left(\mathrm{UC}_{\mathrm{t}}\right)$ varies as follows:

$$
\mathrm{UC}_{\mathrm{st}}=\mathrm{UC}_{\text {minimum }}+\mathrm{UC}_{\text {decrease }} /\left(\mathrm{c}+\mathrm{dQ}_{\mathrm{st}}\right),
$$

where $\mathrm{UC}_{\text {minimum }}$ is the minimum possible unit cost, $\mathrm{UC}_{\text {decrease }}$ is the asymptotic decrease in unit cost over time, $\mathrm{Q}_{\mathrm{t}}$ is the industry unit sales volume (from Equation 5), and $\mathrm{c}$ and $\mathrm{d}$ are constants. In each learning curve, the unit cost is set at a value of $\$ 100\left(\mathrm{UC}_{\text {minimum }}+\mathrm{UC}_{\text {decrease }}=\$ 100\right)$. In the baseline scenario, unit costs decrease asymptotically from $\$ 100$ to $\$ 50$ over the course of the product life cycle $\left(\mathrm{UC}_{\text {minimum }}=\$ 50, \mathrm{UC}_{\text {decrease }}=\$ 50\right)$. Note that the unit costs apply to the industry (product life cycle) as a whole. We operationalize an individual supplier's unit cost savings as a percentage of industry unit cost savings based on the supplier's market share at time $t$.

Marketing dollars are required to build relationships and associated internal resources to move customers from strangers, to acquaintances, to friends, to partners (Fornell and Wernerfelt 1987). Recall that customer problem-solving decisions include the decision of whether to move the relationship with a supplier to a higher level. Because customer risks and resource sharing increase as a relationship grows, it should be more expensive to convince a customer to become a partner than to become a friend or acquaintance. In the baseline scenario, the acquisition cost of converting a customer to an acquaintance, friend, and partner is $\$ 100$, $\$ 150$, and $\$ 200$, respectively. Suppliers also incur some cost 
associated with gaining customers from competitors at a given relationship level, that is $\mathrm{AC}_{\text {st Gaining }}, \mathrm{FC}_{\text {st Gaining, and }}$ $\mathrm{PC}_{\mathrm{st}}$ Gaining (acquaintance cost of gaining, friend cost of gaining, and partner cost of gaining for supplier $s$ at time $t$ ) in Equation 4. In the baseline scenario, we set this cost equal to $\$ 100, \$ 200$, and $\$ 300$, respectively, positing that it should be more expensive to switch a customer from competitor to competitor than it is to create a closer relationship with a customer already in the portfolio.

When a customer moves from being a stranger to an acquaintance, supplier s receives a base customer revenue $\left(\mathrm{CR}_{\mathrm{st}}\right.$ in Equation 4$)$ in each time period that the customer is retained. Following the relationship typology logic in Table 1 , when customer demand is met through differentiation, friendships are formed, which yields a friendship premium for the supplier $\left(\mathrm{FP}_{\mathrm{st}}\right)$. When customer demand is met through an even greater investment in customization, partnerships are formed, which yields a partnership premium for the supplier $\left(\mathrm{PP}_{\mathrm{st}}\right)$. We held the base revenue for acquaintances, friends, and partners constant at $\$ 100$ across scenarios. In the baseline scenario, moving a customer to become a friend and partner adds a premium of $\$ 25$, such that the overall customer revenue (not including unit cost) equals $\$ 100, \$ 125$, and $\$ 150$ for acquaintances, friends, and partners, respectively.

To operationalize the CPLV model, we needed to make an assumption about the probability that a supplier is able to convert a customer to a closer relationship. We set this probability to .25 in the baseline scenario. We make other simplifying assumptions at this point. Our market growth curve in Equation 5 defines how many customers are in the market at a given point. Using a spreadsheet database, the simulation multiplies the number of new customers entering the market in a period by a supplier's probability of creating acquaintances. This probability determines the share of new customers entering the market that are acquaintances of supplier s at time t. Competitors acquire all remaining acquaintances that are entering the market at time t. We then take into account that the market-matching process requires some minimum time period before customers are in a position to move to a higher relationship. For example, it takes time for customers to solve problems and for suppliers to allocate resources to create differential and customized value. The simulation assumes that it takes a minimum of 10 market periods for any customer either to transition to a closer relationship with the same supplier or to switch to the same type of relationship with a different supplier. In our preliminary tests of the simulation, we also set the minimum time equal to 20 market periods, and we found that the pattern of results was robust.

We also made an assumption about competitors. After being an acquaintance for ten periods, there is some probability that a customer is converted to a higher-level relationship, is lost to the competition, or remains at the current relationship level (where the sum of the probabilities of converting and losing customers must be less than or equal to one). To calculate the total number of customers at any given relationship stage for supplier s, the simulation first determines the number of customers that competitors have at each relationship stage at time t. To make this determina- tion, we assume that the competitors' probabilities of creating friends and partners are equal to .25 , which is the baseline level of the probabilities for our target supplier s. This enables us to simulate situations in which the target supplier's probabilities and the competitors' probabilities are equal (the baseline), the supplier is better than competitors at creating relationships, and the supplier is worse than competitors at creating relationships.

Following Postulate 1a, the deeper the relationship that customers form with a particular supplier, the more difficult it is to move customers from one competitor to another. The baseline scenario reduces the probability of gaining one of the competitor's acquaintance customers versus gaining one of the friend customers from .25 to .125 , and the probability of gaining one of the partner customers is reduced to .0625 . This represents a $50 \%$ decrease in the switching probabilities for each relationship level. We set the probabilities of losing one of the focal supplier's customers to a competitor in the same way and with the same values in the baseline model.

In summary, the baseline simulation scenario uses the diffusion curve defined in Equation 5 as a base. We applied the conversion and switching probabilities to this customer base to determine the number of acquaintances, friends, and partners for both the focal supplier s (Equations 1-3) and competitors as a whole in each of 100 time periods as the market evolves. We then used these relationships as well as the cost and margin parameters to determine the contribution of each type of relationship in the supplier's portfolio over time as well as overall CPLV using Equation 4. The aggregated CPLV results for the simulations are shown in Table 2 .

Figure 2 shows the contributions by market period and relationship type for the baseline scenario. Figure 2 illustrates how acquaintances, friends, and partners make their greatest contribution to overall CPLV at different points in time. Although the baseline scenario suggests that acquaintances contribute the most to CPLV over time (friends and partners add value as the market matures), note that this is a direct function of the input used. It is more important to focus on relative changes as we vary the parameters.

In the following sections, we first examine how variation in economies of scale affects the development of the portfolio. We then examine how differences in competitive capabilities reflected in probabilities of converting customers to closer relationships and gaining or losing customers at a given relationship level affect the portfolio over time. Finally, we illustrate the dynamics of industry shocks on CPLV, especially as they relate to sudden changes in unit costs and relationship premiums.

\section{Economies of Scale}

To determine the effect of differences in economies of scale, we developed scenarios that deviate from the baseline (both greater and lesser economies of scale). Scenario 2 illustrates a situation in which the economies of scale are lower than the baseline. This is typical of many service firms and industries in which the more service that is added to the overall product offering, the more involved are the human resources of the firm and customers themselves, which lowers produc- 
TABLE 2

\section{Baseline scenario}

Decreased economies of scale

3. Increased probability of relationship conversion

4. Increased probability of converting

acquaintances,

decreased probability of converting partners

5. Increased probability of gaining customers from competitors

6. Cost shocks over time
Parameter Values, Relationship Contributions, and Overall CPLV for Different Scenarios
Acquaintances'

Acquaintan
Dollar

Contribution

(Percentage of

CPLV)

Friends' Dollar

Contribution

Parameter Values Varied

Economies of scale $=50 \%$ industry maximum

Probability of converting relationships $=.25$ for all relationships

$\$ 271,604,881$

$(60.6 \%)$

CPLV)

Partners' Dollar
Contribution

Contribution

CPLV)

CPLV in Dollars

(Percentage of

CPLV)

Probability of gaining relationships $=.25$

(acquaintances), .125 (friends), and .0625 (partners)

Probability of losing relationships $=.25$

(acquaintances), .125 (friends), and .0625 (partners)

Economies of scale $=20 \%$ industry maximum

Probability of converting relationships $=.25$ for all relationships

Probability of gaining relationships $=.25$

(acquaintances), .125 (friends), and .0625 (partners)

Probability of losing relationships $=.25$

(acquaintances), .125 (friends), and .0625 (partners)

Economies of scale $=50 \%$ industry maximum

Probability of converting relationships $=.50$ for all relationships

Probability of gaining relationships $=.25$

(acquaintances), .125 (friends), and .0625 (partners)

Probability of losing relationships $=.25$

(acquaintances), .125 (friends), and .0625 (partners)

Economies of scale $=50 \%$ industry maximum

Probability of converting relationships $=.50$

Probability of gaining relationships $=.25$

Probability of losing relationships $=.25$

Economies of scale $=50 \%$ industry maximum

Probability of converting relationships $=.25$ for all

Probability of gaining relationships $=.50$

Probability of losing relationships $=.25$

$\$ 128,384,427$

$(28.7 \%)$

$\$ 48,000,757$

(10.7\%)

\$ 447,990,064

$447,990,06$
$(100 \%)$

$\$ 83,894,091$

(38.4\%)

\$ $94,337,516$

(43.2\%)

$\$ 40,099,941$

(18.4\%)

$\$ 218,331,548$

(100\%)

$\$ 374,213,019$

(34.5\%)

(30.4\%)

$\$ 380,446,304$

(35.1\%)

$\$ 1,083,431,180$

(100\%) (acquaintances), .25 (friends), and .125 (partners)

(acquaintances), .125 (friends), and .0625 (partners)

(acquaintances), .125 (friends), and .0625 (partners) relationships

(acquaintances), .25 (friends), and .125 (partners)

(acquaintances), .125 (friends), and .0625 (partners)

$\$ 556,162,600$

$(61.9 \%)$

Cost shocks of $\$ 33.33$ introduced in periods 34 and 67.
$(69.2 \%)$
$\$ 51,992,103$

$(5.8 \%)$
$\$ 170,023,053$

$(23.2 \%)$
$\$ 55,387,093$

$(7.6 \%)$
$\$ 898,119,861$

(100\%)
(100\%)
$\$ 731,149,838$
\$ $62,931,022$

(33.1\%)
$\$ 88,863,027$

$(46.8 \%)$

$$
\text { Other parameters same as baseline scenario. }
$$
\$ $38,172,167$
$(20.1 \%)$


tivity (Huff, Fornell, and Anderson 1996). In this scenario, industrywide unit costs decrease asymptotically from $\$ 100$ to $\$ 80$ over the course of the product life cycle $\left(\mathrm{UC}_{\text {minimum }}=\right.$ $\$ 80, \mathrm{UC}_{\text {decrease }}=\$ 20$ ), which compares with the lower limit of $\$ 50$ in the baseline scenario. We operationalize an individual supplier's actual share of the cost savings as the percentage of industry unit cost savings based on the supplier's market share at time t. For example, the target supplier's market share reaches $36 \%$ by Period 100 in the baseline scenario. This translates into a unit cost of approximately $\$ 82$ when the industry maximum is $50 \%$ (baseline scenario) and $\$ 93$ when the industry maximum is $20 \%$ (Scenario 2).

The results for Scenario 2 are shown in Figure 3. A comparison of Figures 2 and 3 (and the results in Table 2) illustrates two important predictions of the typology and CPLV model. First, as economies of scale decrease, the overall

\section{FIGURE 2 \\ Contributions over Time for Baseline Scenario (Scenario 1)}

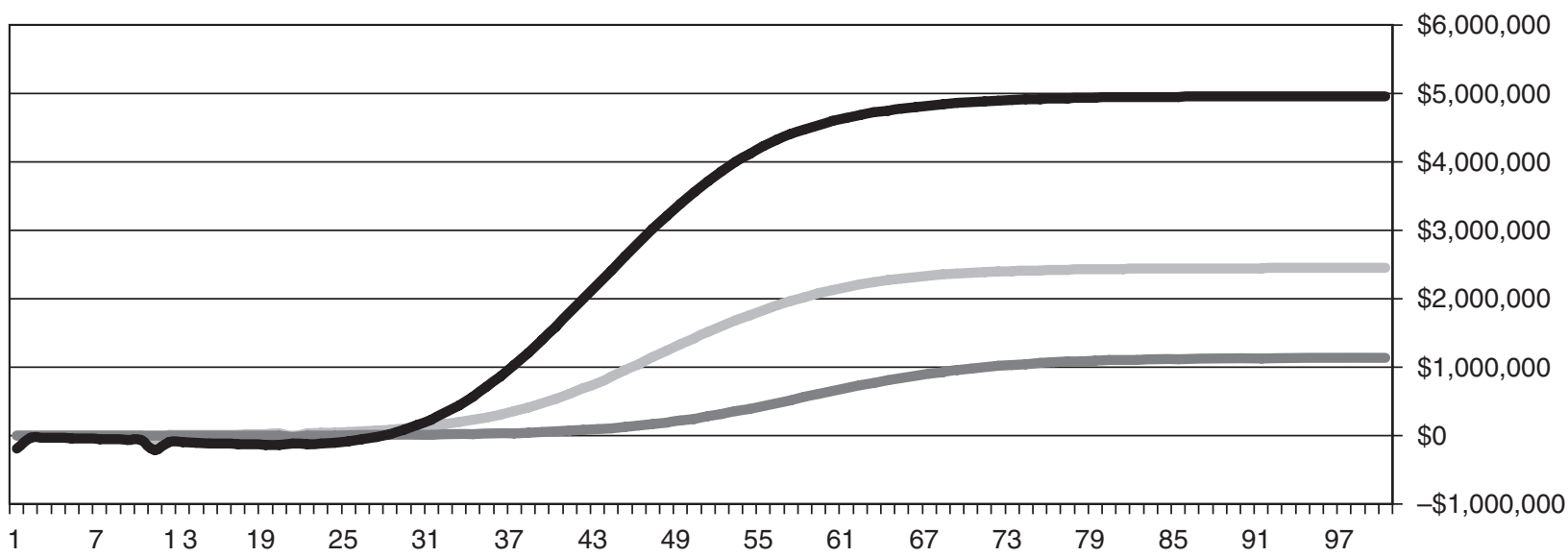

Time Period

\begin{tabular}{|ll|}
\hline Acquaintances' contribution & Friends' contribution
\end{tabular}

FIGURE 3

Contributions over Time When Economies of Scale Decrease (Scenario 2)

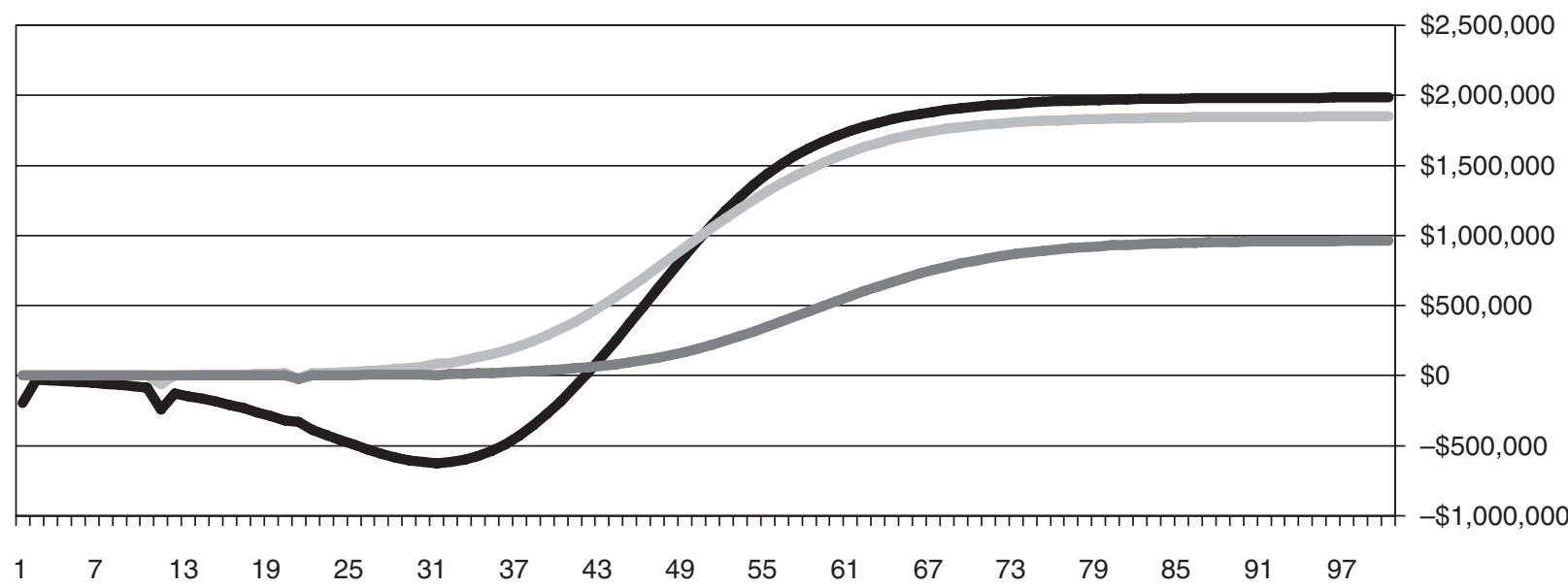

Time Period

Acquaintances' contribution $\quad$ Friends' contribution Partners' contribution


value of CPLV decreases rather dramatically. The CPLV drops from $\$ 448$ million in the baseline scenario to just $\$ 218$ million when economies of scale are small (see Table 2 ). Second, the relative contribution of acquaintances is much more susceptible to changes in economies of scale than are the contributions of friends and partners. In Figure 3 , acquaintances are no longer the most profitable relationship category early in a market's growth; acquaintances are a losing proposition over the early market periods because the scale advantages of growth have yet to compensate for the cost of creating the relationships. The contribution of friendships toward overall CPLV increases from 29\% in the baseline to $43 \%$ in Scenario 2, and the contribution of partnerships increases from $11 \%$ to $18 \%$. In contrast, the contribution of acquaintances falls from $61 \%$ in the baseline to $38 \%$ in Scenario 2. When economies of scale are even higher than in the baseline scenario $(80 \%$ maximum unit cost decrease for the industry), the contribution of acquaintances increases relative to both friends and partners such that arm's-length relationships dominate the market over time. The simulations illustrate the inherent challenge with acquaintances. Because the margins on acquaintances are much lower than the margins on friends and partners, their contribution to CPLV is more susceptible to changes in economies of scale.

The results help explain the basic shift in marketing thinking as economies have matured over the past 50 years. The loss of economies of scale has resulted in a shift in strategy that once focused on market share and arm's-length relationships to a focus on closer relationships with customers. Not only are friendships and partnerships more profitable as a market matures, but also their attractiveness increases in a customer portfolio when scale economies are limited.

\section{Competitive Capability in Converting Relationships}

A firm's particular competitive capability to convert customers to closer relationships affects the attractiveness of different relationships in its portfolio. We conducted various simulations of the CPLV model to understand these implications. Scenario 3 illustrates a situation in which firms have the requisite skills to increase the probability of converting relationships to a level of .50 for each type of relationship, compared with a level of .25 in the baseline scenario. That is, the absolute level of conversion probabilities increases compared with the baseline, but it remains constant across relationships. Figure 4 shows the contribution over time by relationship type for Scenario 3. Note that there is a systematic transition over time where acquaintances and friends make the greatest contributions early in the market, but by Period 61, partners come to dominate the portfolio. Moreover, the CPLV for Scenario 3 (see Table 2) grows to more than twice the value of the baseline CPLV ( $\$ 1.083$ billion versus $\$ 448$ million). We formalize these findings in the following proposition:

$\mathrm{P}_{1}$ : As the competitive capability of converting customers to closer relationships increases relative to competition, (a) CPLV increases, and (b) closer relationships make a greater contribution to CPLV over a longer period of time.

Put simply, $\mathrm{P}_{1}$ captures how a firm that is superior at building closer relationships creates more value through those relationships over time.

\section{Competitive Capability in Creating Acquaintances}

More notable are firm-level differences with respect to the ability to create a particular type of relationship. To illustrate, Scenario 4 operationalizes a set of conversion proba-

FIGURE 4

Contributions over Time When Probability of Relationship Conversion Increases (Scenario 3)

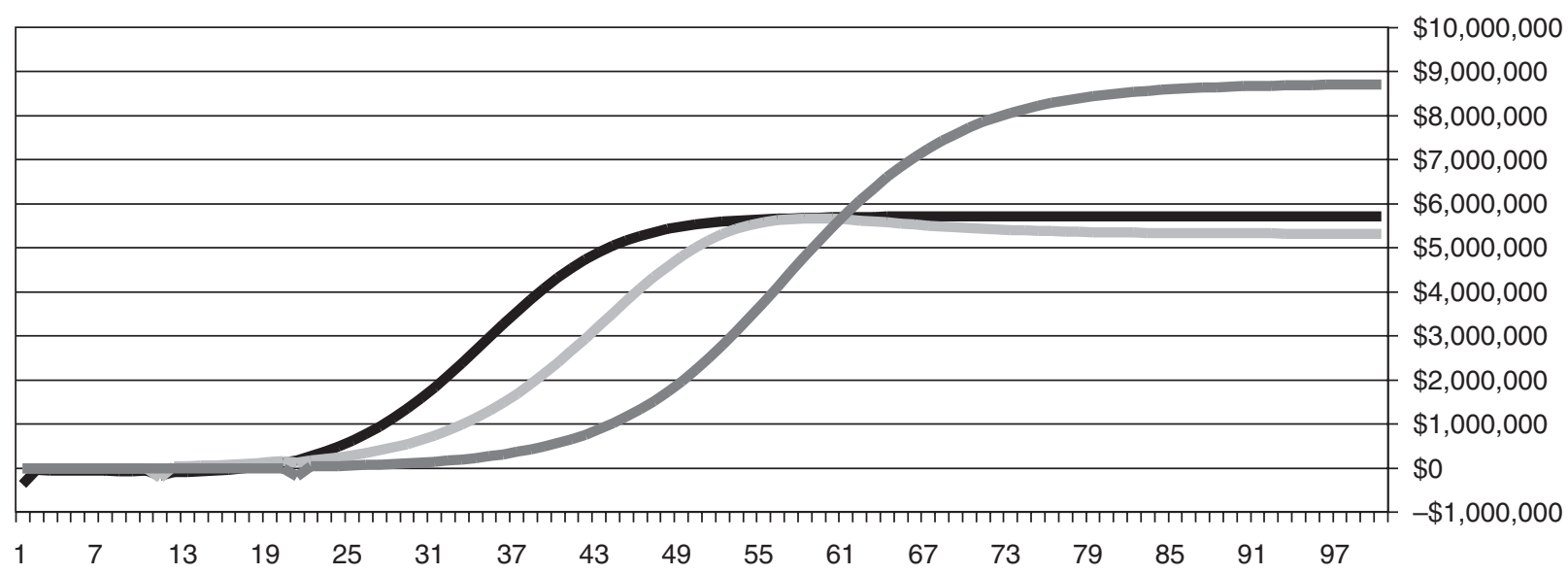

Time Period

\begin{tabular}{|ll|}
\hline Acquaintances' contribution & Friends' contribution $\quad$ Partners' contribution \\
\hline
\end{tabular}


bilities that vary by relationship level, in which it is easier for the supplier to create acquaintances $(p=.50)$ than friends $(p=.25)$ or partners $(p=.125)$ in any given time period. Again, the probability that competitors are able to create either friends or partners is held constant at .25 (the baseline level). Variation of the probabilities by relationship level offers important insights into the dynamics of a customer portfolio. Differences in the contributions over time are not as revealing as the change in the ultimate value of acquaintances, friends, and partners, as reported in Table 2. For firms that are better at creating acquaintances than friends and partners, the CPLV equals $\$ 898$ million, which is more than double the baseline CPLV of $\$ 448$ million. Although partnerships make up a larger proportion of CPLV in the baseline scenario, the contribution of each relationship type declines. These findings lead to the following proposition:

$\mathrm{P}_{2}$ : As the capability of creating distant relationships increases relative to the capability of converting customers to closer relationships, (a) CPLV increases, and (b) distant relationships make a greater relative contribution to CPLV over a longer period of time.

The important insight from $\mathrm{P}_{2}$ is that a key to creating value through friendships and partnerships is a firm's ability to bring customers into the portfolio as acquaintances in the first place. If a firm specializes in creating close relationships at the expense of being poor at converting strangers into acquaintances, profitability decreases dramatically. Although closer relationships make greater relative contributions to the customer portfolio, there is a much smaller customer base to draw on, such that all relationship types are less profitable. Put simply, it is better to generate a larger bucket of distant relationships than a smaller bucket of close relationships. Without the larger, leakier bucket, the number of close relationships the supplier can form is inherently restricted.

\section{Competitive Capability of Gaining and Keeping Relationships}

Our relationship typology suggests that the deeper the relationship customers form with a particular supplier, the more difficult it is to move customers from one competitor to another. That is why probabilities of gaining and losing customers decrease from acquaintances, to friends, to partners in each scenario. However, the level of the probabilities should again vary with a supplier's marketing capabilities. In Scenario 5, we assume that the supplier is twice as likely to gain customers from competitors at a given relationship level (probabilities of gaining customers are .5, .25, and .125 for acquaintances, friends, and partners, respectively) as they are to lose customers to competitors (probabilities of losing customers are .25, .125, and .0625 for acquaintances, friends, and partners). This is a situation in which the supplier has relatively strong marketing capabilities of gaining versus losing customers.

The results for Scenario 5 vary from the baseline scenario in two important ways. First, the overall value of CPLV increases by $63 \%$ (from $\$ 448$ million to $\$ 731$ million). Second, and more important from a portfolio management standpoint, the relative contribution of acquaintances in the overall CPLV increases from $61 \%$ to $69 \%$ of the portfolio. The relative contributions of friendships and partnerships decrease from $29 \%$ and $11 \%$, respectively, in the baseline scenario to $23 \%$ and $8 \%$ in Scenario 5. These findings provide the basis for the following proposition:

\section{$\mathrm{P}_{3}$ : As the competitive capability of gaining and keeping cus- tomers increases, (a) CPLV increases, and (b) distant rela- tionships make a greater contribution to CPLV than do closer relationships over time.}

Particularly notable is the flip side of $\mathrm{P}_{3}$. If a supplier is relatively poor at retaining customers, it must rely more on friendships and partnerships to survive. The weaker a firm's relative switching probabilities, the more it benefits from closer relationships. Such a firm is simply less likely to lose customers that manage to become friends and partners. This result is consistent with research by Ghosh and John (2002), who find that firms operating from a position of strength are less likely to create close alliances with suppliers. This result is also consistent with the research of Rust, Moorman, and Dickson (2002), who examine whether it is more profitable for firms to pursue a strategy of quality improvements to enhance customer satisfaction, which subsequently will attract and keep customers, or to pursue a strategy of quality improvements to enhance cost efficiency to improve margins. On the basis of a sample of established companies, they find that firms that emphasize building a larger customer base perform best.

\section{Shocks in the System}

Finally, we use the CPLV model to examine the effects of shocks in the system on the value of different relationships in a portfolio. We explored two types of shocks that directly affect contributions: sudden changes in unit costs and sudden changes in revenue premiums. Periodically, companies incur costs associated with, for example, point-in-time investments in technology upgrades, expansion of a physical plant, or the purchase of new equipment. To illustrate this situation, Scenario 6 illustrates the baseline scenario while adding unit costs that amount to one-third of the Period 0 unit cost base of $\$ 100$ (i.e., \$33.33) in Period 34 and again in Period 67. For simplicity, we reduced the additional unit costs over time at the same rate as the original unit costs.

The results are reported in Table 2 and Figure 5, which illustrates how the cost shocks result in greater swings in the contribution of acquaintances in relation to friends and partners. Even though the contributions from acquaintances remain high, the contribution risks are also high. Partners and friends show less fluctuation in their contributions over time. Because the margins are relatively thin for acquaintance customers, the sudden increases in costs have more dramatic effects on their contributions. Another notable result from Scenario 6 is that the relative contribution of friends and partners increases to a point at which friends provide the greatest overall contribution because they effectively balance contribution risk and return.

We also explored shocks or sudden reductions in the revenue premiums, as might occur when economic conditions are particularly weak (customers spend less and are more price sensitive). As we expected, the revenue premium 
FIGURE 5

Contributions over Time When Cost Shocks Occur

(Scenario 6)

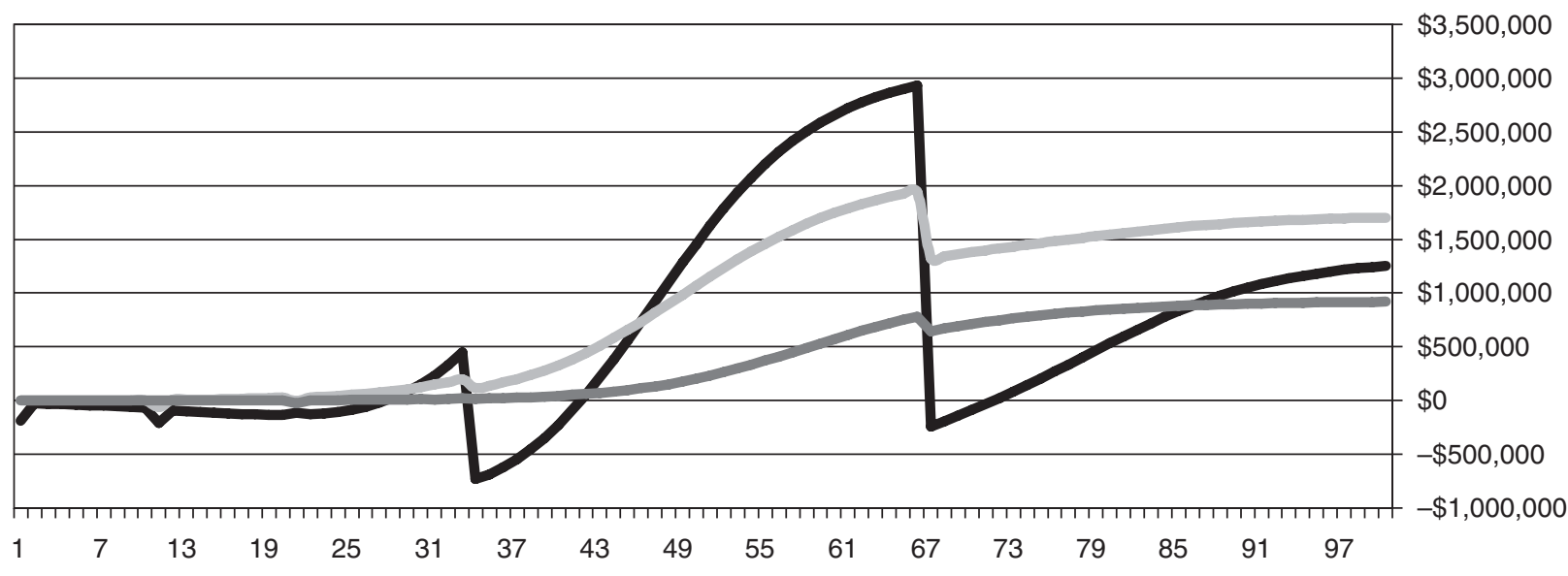

Time Period

shocks reduce the relative contribution of partners and friends and make the contributions less predictable. These results provide the basis for the following proposition:

$\mathrm{P}_{4}$ : When a market is subject to sudden increases in unit costs (reduced revenue premiums), (a) closer (distant) relationships make a greater contribution to CPLV than do distant (closer) relationships, and (b) closer relationships have less (more) variance or risk associated with their contributions than do distant relationships.

In our discussion, we explore the firm-level implications of this risk-return trade-off.

\section{Sensitivity Analyses}

Recall that we simulated the CPLV model over various parameter values that we have not reported. We summarize these results here to evaluate the sensitivity of our propositions to wider variation in the parameters. Reducing the relationship premiums from closer relationships to relatively low values (an additional $\$ 5$ for friends and $\$ 10$ for partners versus $\$ 25$ and $\$ 50$ for the baseline scenario) or increasing the premiums to double the baseline scenario (\$50 for friends and $\$ 100$ for partners) only affects the magnitude of the differences across relationships and does not change the relative predictions. In general, as the relationship premiums from closer relationships increase, the positive contributions from the relationships increase and occur earlier in a market's growth. Similar results occur when (1) the probability of converting customers to closer relationships continues to increase relative to competitors and (2) the probability of converting friends to partners increases relative to the probability of converting stranger to acquaintances. The various simulations show that $\mathrm{P}_{1}-\mathrm{P}_{4}$ are not sensitive to alternative starting values in the baseline scenario.
We also simulated what happens when the base revenue per customer for supplier s at time $t\left(\mathrm{CR}_{\mathrm{st}}\right.$ in Equation 4$)$ gradually erodes over time, as often occurs when competition reduces base margins. Similar to our findings for cost shocks, acquaintances are much more sensitive to these changes because their margins are lower. One scenario decreased base customer revenues by $\$ .25$ each period. The contribution of friends dominated the scenario (CPLV of $\$ 128$ million) and partners were profitable (CPLV of $\$ 48$ million), but acquaintances became rather unprofitable (CPLV of $-\$ 40$ million), though the acquaintances provided the base from which the more profitable friends and partners evolved.

\section{Discussion}

Marketing has evolved over time from an emphasis on market share and size to an emphasis on developing relationships with customers as the key to profitability. An understanding of this evolution and of what drives profitability over time requires a dynamic theory of exchange relationships that encompasses the trade-offs between the two sources of profitability. Scale economies of growth emphasize the need to move customers "in the system" to lower costs. In contrast, CLV emphasizes the need to build relationships and to keep customers over time to capture the "back loading" of customer revenues. We have contributed to this theory by developing a typology of exchange relationship mechanisms that capture fundamentally different forms of value creation. Our typology suggests that marketers take a more comprehensive view of offensive and defensive marketing strategies than currently exists. The purpose of offensive marketing is not only to increase a market but also to provide a basis for customer portfolio devel- 
opment. The purpose of defensive marketing is not simply to prevent customer defections but also to create value through relationship development.

The overall value of a firm's customer portfolio is an aggregation of the contribution from individual exchange relationships over time. At a basic level, suppliers create acquaintances by providing parity value, friends by providing differential value, and partners by providing customized value. Prevailing theories and strategies in marketing argue for building friendships (e.g., brand relationships) and partnerships. Brand building has been the primary means of building a purchase-consumption-repurchase relationship with suppliers (Aaker 1996). Theories of customer behavior have similarly focused on brand concepts (Howard 1977, 1983) and loyalty, defined as repeat purchase and related behaviors (e.g., repurchase intentions, word of mouth, price sensitivity) (Bloemer, Ruyter, and Wetzels 1998). Partnering is usually connected to business-to-business marketing, in which commitment-based resource sharing is widely recommended (Moorman, Zaltman, and Deshpandé 1992; Morgan and Hunt 1995). The theoretical framework presented here should open the eyes of the marketing community to focus more on accumulated value creation of a customer portfolio, not on the value created in single relationships. Although in some situations the accumulated value created in a customer portfolio may be dominated by friends and partners, acquaintances are more likely to be the cornerstone of a firm's portfolio and the primary source of economies of scale. Thus, managers should not necessarily stop doing business with customers that are less profitable on an individual basis.

We illustrated the complexity of how value is created in a portfolio of relationships in several scenarios. One of the more interesting scenarios shows that a leaky bucket of customers may create more value than a tight bucket. If a firm specializes in creating close relationships at the expense of acquiring acquaintances, profitability decreases dramatically. The important implication is that the key to creating value through closer relationships is rooted in a firm's ability to bring weaker relationships into a portfolio in the first place. Another noteworthy and important insight is how sensitive portfolio value is to variations in economies of scale. If economies of scale are low, as they are for many types of services, closer relationships tend to generate more value than distant relationships. Thus, the more a firm is positioned toward product offerings with low economies of scale (i.e., high personal-service component), the stronger it must be in developing and keeping closer relationships.

Another scenario illustrates the risk-return trade-offs due to unexpected market changes. When the uncertainty is related to cost increases, closer relationships are better buffers toward unwanted variance in contributions. The implication is that intermediate-level relationships (i.e., the friends in our typology) provide a balance of risk and return. Friendships created through the development of strong brands should be particularly attractive when firms face considerable economies of scale (where distant relationships are relatively more profitable) but costs are uncertain (where closer relationships lower contribution risk). When uncertainty is related to relationship premiums, as when consumer spending varies over time, more distant relationships are better buffers against contribution variance.

A natural next step is to begin empirical investigations of our underlying postulates and resulting propositions. There is also a need to explore various dynamic factors that are certain to affect CPLV. These include demand shocks due, for example, to changes in technology or major events in society. In the current model, we have assumed a rather simplistic construction of the market in terms of segments (customers are only differentiated as acquaintances, friends, and partners). The validity of our theory and model will continue to improve as we model other types of segments in combination with the typology presented here. An example is segments based on purchasing volume (i.e., light versus heavy users). For example, what are the implications if the heavy users in the market are partners or acquaintances? Another segment-related issue is whether there are customers in the market that do not move through the progression from acquaintances, to friends, and to partners, but may begin directly as a friend or a partner customer. An implication of this is that the importance of acquaintances observed in the presented scenarios would be less. Thus, we require a deeper understanding of how different types of segments affect the value of the customer portfolio over time. We need to explore firm-level dynamics and their influence on customer portfolios as well. If first movers focus more on building acquaintances, should subsequent entrants invest more exclusively in the brands required to build friendships or in the firm-level capabilities required to build partnerships? Another issue is the effect of improvements in marketing capabilities over time. If a firm can improve either its acquisition skill or its relationship development skill, which would have the greatest impact in different circumstances?

Our intent has been to introduce a conceptual framework for how companies can better manage their customer portfolios. A natural question, then, is, How can we relate this conceptualization to a practical or applied level? A natural starting point for a company is its current portfolio of customers and, if available, its customer relationship management databases. A premise of our CPLV model is that customers should be classified according to how relationship value is created both for the customer and for the company. Thus, a challenge would be to develop measurement instruments or classification schemes that sort customers according to their value creation (e.g., relationship premiums, conversion probabilities, switching probabilities). Instruments are also needed to assess relative firm capabilities and the costs of customer acquisition and development. Finally, methods are required to analyze the dynamics of exchange relationships in a firm's portfolio as markets evolve that capture the interplay among customers, competitors, technology, and other factors. Moving the conceptual framework to an empirical and applied level is a challenge and an opportunity for both academics and practicing managers.

We provide a foundation for answering the questions raised by viewing a firm's customer base as a portfolio of exchange relationships that create value in fundamentally different ways over time. Our framework, relationship typology, postulates, and propositions provide scholars working in marketing and customer relationship management with a 
more dynamic approach to building a sustainable competitive advantage. A firm's portfolio contains a combination of acquaintances, friends, and partners that is constantly changing. This requires decisions as to when to invest in relationships based on their attractiveness over time. Our approach provides a starting point for thinking about the conditions in which different relationship types should be the focus of a firm's customer portfolio.

\section{REFERENCES}

Aaker, David A. (1996), Building Strong Brands. New York: The Free Press.

Alderson, Wroe (1957), Marketing Behavior and Executive Action: A Functionalist Approach to Marketing Theory. Homewood, IL: Richard D. Irwin.

- (1965), Dynamic Marketing Behavior: A Functionalist Theory of Marketing. Homewood, IL: Richard D. Irwin.

Anderson, Eugene W., Claes Fornell, and Roland T. Rust (1997), "Customer Satisfaction, Productivity, and Profitability: Differences Between Goods and Services," Marketing Science, 16 (2), 129-45.

Bagozzi, Richard P. (1975), "Marketing as Exchange," Journal of Marketing, 39 (October), 32-39.

Baker, William E. and James M. Sinkula (1999), "The Synergistic Effect of Market Orientation and Learning Orientation on Organizational Performance," Journal of the Academy of Marketing Science, 27 (Fall), 411-27.

Bendapudi, Neeli and Leonard L. Berry (1997), "Customers' Motivations for Maintaining Relationships with Service Providers," Journal of Retailing, 73 (1), 15-37.

Berry, Leonard L. (1980), "Services Marketing Is Different," Business, 30 (May), 24-29.

Best, Roger J. (2000), Market-Based Management: Strategies for Growing Customer Value and Profitability, 2d ed. Upper Saddle River, NJ: Prentice Hall.

Blattberg, Robert C., Gary Getz, and Jacquelyn S. Thomas (2001), Customer Equity: Building and Managing Relationships as Valuable Assets. Boston: Harvard Business School Press.

Bloemer, Jose, Ko de Ruyter, and Martin Wetzel (1998), "Linking Perceived Service Quality and Service Loyalty: A MultiDimensional Perspective," European Journal of Marketing, 33 (11-12), 1082-1106.

Buzzell, Robert D. (1966), "Competitive Behavior and Product Life Cycles," in New Ideas for Successful Marketing: Proceedings of the 1966 World Congress, John S. Wright and Jac L. Goldstucker, eds. Chicago: American Marketing Association, 46-68.

- and Bradley T. Gale (1987), The PIMS Principles. New York: The Free Press.

Cannon, Joseph P. and William D. Perreault Jr. (1999), "Buyer-Seller Relationships in Business Markets." Journal of Marketing Research, 36 (November), 439-60.

Christopher, Martin, Adrian Payne, and David Ballantyne (2002), Relationship Marketing: Creating Stakeholder Value. Woburn, MA: Butterworth-Heinemann.

Coase, R.H. (1937), "The Nature of the Firm," in Readings in Price Theory, George J. Stigler and Kenneth E. Boulding, eds. Chicago: Richard D. Irwin, 331-51.

Cook, Karen S. and Richard M. Emerson (1978), "Power, Equity, and Commitment in Exchange Networks," American Sociological Review, 43 (October), 721-38.

Day, George S. (1984), Strategic Market Planning: The Pursuit of Competitive Advantage. Minneapolis: West Publishing Company.

(1997), "Maintaining the Competitive Edge: Creating and Sustaining Advantages in Dynamic Competitive Environments," in Wharton on Dynamic Competitive Strategy, George S. Day and David J. Reibstein, eds. New York: John Wiley \& Sons, 48-75.

- (2000), "Managing Market Relationships," Journal of the Academy of Marketing Science, 28 (1), 24-30.
_ and Robin Wensley (1988), "Assessing Advantage: A Framework for Diagnosing Competitive Superiority," Journal of Marketing, 52 (April), 1-20.

Dickson, Peter R. (1983), "Distributor Portfolio Analysis and the Channel Dependence Matrix: New Techniques for Understanding and Managing the Channel," Journal of Marketing, 47 (Summer), 35-55.

(1992), "Toward a General Theory of Competitive Rationality," Journal of Marketing, 56 (January), 69-83.

Dwyer, F. Robert, Paul H. Schurr, and Sejo Oh (1987), "Developing Buyer-Seller Relationships," Journal of Marketing, 51 (April), 11-27.

Dyer, Jeffrey H. and Harbir Singh (1998), “The Relational View: Cooperative Strategy and Sources of Interorganizational Competitive Advantage." Academy of Management Review, 23 (4), 660-79.

Edvardsson, Bo, Michael D. Johnson, Anders Gustafsson, and Bodil Sandén (2000), New Service Development and Innovation in the New Economy. Lund, Sweden: Studentlitteratur.

Ehrenberg, A.S.C. (1972), Repeat-Buying: Theory and Applications. New York: Elsevier.

Ettlie, John E. (2000), Managing Technological Innovation. New York: John Wiley \& Sons.

Fiocca, Renato (1982), "Account Portfolio Analysis for Strategy Development," Industrial Marketing Management, 11 (February), 53-62.

Fornell, Claes (1992), "A National Customer Satisfaction Barometer: The Swedish Experience," Journal of Marketing, 56 (January), 6-21.

$\longrightarrow$, Michael D. Johnson, Eugene W. Anderson, Jaesung Cha, and Barbara Everitt Bryant (1996), "The American Customer Satisfaction Index: Nature, Purpose, and Findings," Journal of Marketing, 60 (October), 7-18.

- and Birger Wernerfelt (1987), "Defensive Marketing Strategy by Customer Complaint Management: A Theoretical Analysis, Journal of Marketing Research, 24 (November), 337-46.

Ghosh, Mrinal and George John (2004), "Governance Value Analysis and Marketing Strategy," working paper, University of Michigan Business School.

Gummesson, Evert (1994), "Making Relationship Marketing Operational," International Journal of Service Industry Management, 5 (5), 5-20.

- (2002), Total Relationship Marketing, 2d ed. Oxford, UK: Butterworth-Heinemann.

Gupta, Sunil and Donald R. Lehmann (2003), "Customers as Assets," Journal of Interactive Marketing, 17 (Winter), 9-24.

Gustafsson, Anders and Michael D. Johnson (2003), Competing in a Service Economy: Building a Competitive Advantage Through Service Development and Innovation. San Francisco: Jossey-Bass.

Hayek, Frederick A. (1978), New Studies in Philosophy, Politics, Economics, and the History of Ideas. London: Routledge and Kegan Paul.

Heide, Jan B. (1994), "Interorganizational Governance in Marketing Channels," Journal of Marketing, 58 (January), 71-85.

Hoch, Steven and John Deighton (1989), "Managing What Customers Learn from Experience," Journal of Marketing, 53 (April), 1-20.

Hogan, John E., Katherine N. Lemon, and Roland T. Rust (2002), "Customer Equity Management: Charting New Directions for 
the Future of Marketing," Journal of Service Research, 5 (August), 4-12.

Howard, John A. (1977), Consumer Behavior: Application of Theory. New York: McGraw-Hill.

(1983), "Marketing Theory of the Firm," Journal of Marketing, 47 (Fall), 90-100.

Huff, Lenard, Claes Fornell, and Eugene Anderson (1996), "Quality and Productivity: Contradictory and Complementary," Quality Management Journal, 4 (1), 22-39.

Huffman, Cynthia and Barbara Kahn (1998), "Variety for Sale: Mass Customization or Mass Confusion?" Journal of Retailing, 74 (Winter), 491-513.

Hunt, Shelby D. (1976), "The Nature and Scope of Marketing," Journal of Marketing, 40 (July), 17-28.

- (1983), "General Theories and the Fundamental Explananda of Marketing," Journal of Marketing, 47 (Fall), 9-17.

(1997), "Competing Through Relationships: Grounding Relationship Marketing in Resource Advantage Theory," Journal of Marketing Management, 13 (4), 431-45.

- (2002), Foundations of Marketing Theory: Toward a General Theory of Marketing. London: M.E. Sharpe.

— and Robert M. Morgan (1995), "The Comparative Advantage Theory of Competition," Journal of Marketing, 59 (April), $1-15$.

— and (1996), "The Resource-Advantage Theory of Competition: Dynamics, Path Dependencies, and Evolutionary Dimensions," Journal of Marketing, 60 (October), 107-114.

Johanson, Jan, Lars Hallén, and Nazeem Seyed-Mohamed (1991), "Interfirm Adaptation in Business Relationships," Journal of Marketing, 55 (April), 29-37.

Johnson, Michael D., Anders Gustafsson, Tor Wallin Andreassen, Line Lervik, and Jaesung Cha (2001), "The Evolution and Future of National Customer Satisfaction Index Models," Journal of Economic Psychology, 22 (April), 217-45.

Kohli, Ajay K. and Bernard J. Jaworski (1990), "Market Orientation: The Construct, Research Propositions, and Managerial Implications," Journal of Marketing, 54 (April), 1-18.

Kotler, Philip (1972), “A Generic Concept of Marketing," Journal of Marketing, 36 (April), 46-54.

Krapfel, Robert E., Deborah Salmond, and Robert Spekman (1989), "A Strategic Approach to Managing Buyer-Seller Relationships," European Journal of Marketing, 25 (9), 22-37.

Libai, Barak, Das Narayandas, and Clive Humby (2002), "Toward an Individual Customer Profitability Model: A Segment-Based Approach," Journal of Service Research, 5 (August), 69-76.

Mahajan, Vijay, Eitan Muller, and Frank M. Bass (1995), "Diffusion of New Products: Some Generalizations and Managerial Uses," Marketing Science, 14 (3), G79-G88.

McDonald, Gerald W. (1981), "Structural Exchange and Marital Interaction," Journal of Marriage and the Family, 44 (November), 825-39.

Milgrom, Paul and John Roberts (1992), Economies, Organization, and Management. Englewood Cliffs, NJ: Prentice Hall.

Moorman, Christine, Gerald Zaltman, and Rohit Deshpandé (1992), "Relationships Between Providers and Users of Market Research: The Dynamics of Trust Within and Between Organizations," Journal of Marketing Research, 29 (August), 314-28.

Moorthy, K. Sridhar (1993), "Theoretical Modeling in Marketing," Journal of Marketing, 57 (April), 92-106.
Morgan, Robert M. and Shelby D. Hunt (1994), "The Commitment-Trust Theory of Relationship Marketing," Journal of Marketing, 58 (July), 20-38.

Murphy, Patrick E. and Ben M. Enis (1986), "Classifying Products Strategically," Journal of Marketing, 50 (July), 24-42.

Narver, John C. and Stanley F. Slater (1990), "The Effects of a Market Orientation on Business Profitability," Journal of Marketing, 54 (October), 20-35.

North, Douglas C. (1990), Institutions, Institutional Change, and Economic Performance. Cambridge, UK: Cambridge University Press.

Pine, B. Joseph and James H. Gilmore (1998), "Welcome to the Experience Economy," Harvard Business Review, 76 (July-August), 97-105.

— Don Peppers, and Martha Rogers (1995), "Do You Want to Keep Your Customers Forever?" Harvard Business Review, 73 (March-April), 103-114.

Porter, Michael E. (1985), Competitive Advantage: Creating and Sustaining Superior Performance. New York: The Free Press.

- (1995), "What Is Strategy?" Harvard Business Review, 73 (November-December), 61-78.

Reekie, Duncan and Ronald Savitt (1982), "Marketing Behavior and Entrepreneurship: A Synthesis of Alderson and Austrian Economics," European Journal of Marketing, 16 (7), 55-66.

Reichheld, Frederick R. (1996), The Loyalty Effect: The Hidden Force Behind Growth, Profits, and Lasting Value. Boston: Harvard Business School Press.

Richardson, G.B. (1972), "The Organization of Industry," The Economic Journal, 82 (September), 883-96.

Rust, Roland T., Christine Moorman, and Peter R. Dickson (2002), "Getting Return on Quality: Revenue Expansion, Cost Reduction, or Both?" Journal of Marketing, 66 (October), 7-24.

, Valarie A. Zeithaml, and Katherine N. Lemon (2000), Driving Customer Equity: How Customer Lifetime Value Is Reshaping Corporate Strategy. New York: The Free Press.

Selnes, Fred and James Sallis (2003), "Promoting Relationship Learning," Journal of Marketing, 67 (July), 80-95.

Shostack, G. Lynn (1977), "Breaking Free from Product Marketing," Journal of Marketing, 41 (April), 73-80.

Smith, Amy, Ruth Bolton, and Janet Wagner (1999), "A Model of Customer Satisfaction with Service Encounters Involving Failure and Recovery," Journal of Marketing Research, 36 (August), 356-72.

Spekman, Robert (1988), "Strategic Supplier Selection: Towards an Understanding of Long-Term Buyer-Seller Relationships," Business Horizons, 31 (4), 24-36.

Storbacka, Kaj, Tore Strandvik, and Christian Grönroos (1994), "Managing Customer Relationships for Profit: The Dynamics of Relationship Quality," International Journal of Service Industry Management, 5 (5), 21-38.

Van de Ven, Andrew H. (1976), "On the Nature, Formation, and Maintenance of Relations Among Organizations," Administrative Science Quarterly, 29 (December), 598-621.

Webster, Frederick E., Jr. (1978), "Management Science in Industrial Marketing," Journal of Marketing, 42 (January), 21-27.

Williamson, Oliver E. (1981), "The Economics of Organizations: The Transaction Cost Approach," American Journal of Sociology, 87 (3), 548-77.

(1983), "Credible Commitments: Using Hostages to Support Exchange," American Economic Review, 73 (September), 519-40. 
Copyright of Journal of Marketing is the property of American Marketing Association and its content may not be copied or emailed to multiple sites or posted to a listserv without the copyright holder's express written permission. However, users may print, download, or email articles for individual use. 